\title{
Free flaps in head \& neck surgery as an option for immediate facial reconstruction: Experience in a public institution and literature review
}

\author{
De Rungs- Brown DR ${ }^{1 *}$, Palacios-Juarez J², Garcia- Marquez $\mathrm{AR}^{3}$ and Sandoval- Rodríguez $\mathrm{IJ}^{4}$ \\ ${ }^{1}$ Plastic and Reconstructive Resident, General Hospital of Mexico. \\ ${ }^{2}$ Plastic and Reconstructive Attending, Regional Hospital of Ixtapaluca. State of Mexico. \\ ${ }^{3}$ General Physician, Anahuac University. State of Mexico. \\ ${ }^{4}$ Plastic and Reconstructive Resident, General Hospital of Mexico.
}

\begin{abstract}
Objective: To evaluate and discuss the main free flap reconstructve options for patients with maxilectomy defects and total mandibulectomy in oncological procedures. Design: Retrospective revision of a clinical case and techniques used.

Environment: Tertiary reference center.

Methods: A comparative analysis was carried out with 8 databases in search for articles published in the last 10 years: 9 articles were selected and tested for homogenity of data by using Breslow-Day odds ratio statistical analysis test. The articles were combined and the predictive positive and negative values were calculated by Cochran-Mantel-Haenszel. Findings were identified and compared in the results of different choices of flaps for immediate reconstruction of the maxillofacial region in post-oncological patients. Subsequently, a successful case is described in which the ALT Flap Technique was used inside our institution.

Results: The four main free flaps used in immediate reconstruction of the maxillar región $(n=94.0)$ with the best long term integration response as well as aesthetical and functinoal compliance in a post-oncologicalreconstructive procedure of the facial region were: Radial Forearm Flap, Anterolateral Thigh Flap, FibulaFlexor Hallucis Longus Osteomuscular Flap, Latissimus Dorsi Myocutaneous Flap. We identified 94 patients with maxillar and palatal osteosarcoma in 60\% of the diagnoses, in which the findings for adequate compliance were for each of the flaps: Radial Forearm Flap PPV of 7.9 (7.3-8.5), Anterloateral Thigh Flap PPV of 4.2 (1.1-6.3). 87\% of patients correlated for initial oncological diagnosis with previous biopsy and oncological protocol for disease-free resection. Radial Forearm Flap with a PPV of 2.8 (0.8-8.6) and Anterolateral Thigh Flap, with a PPV of 1.6 (1.0-2.5) which represented 95\% of the procedures with better prognosis correlated with the clinical findings and survival of the flap. 23 patients, who constitute $18 \%$ of the free flaps used, presented complications, and $75 \%$ of the free flaps described did not present any complications.
\end{abstract}

Conclusion: The main procedures for immediate reconstruction of the maxillofacial region were free flaps in $96.1 \%$ of the cases PPV (1.1-3) which was statistically significant. The three main free flaps may show favorable progress if the inclusion criteria are chosen appropriately for the ideal patient, demonstrating that evidencebased microsurgical procedures in maxillofacial reconstruction have the best prognosis, being the Radial Forearm Flap and the Anterolateral Thigh Flap of first choice. The importance of the protocol as well as the choice of patients are the best methods for an adequate reconstruction.

\section{Introduction}

It has been described that the transference of free tissue with microvascular techniques is a unique alternative for the reconstruction of the palate and maxillar región in patients with previous oncological resection and/or after trauma to the facial región $[1,2]$. Reconstruction with free flaps allow for the transfer of adequate amounts of soft tissue and bone in one-step procedures, without the limitations of the length of the pedicle or the geometry of the flap [3-5].

A wide variety of free flap transfers have been used for the reconstruction of the maxillar region, such as Scapular Flap, FibulaFlexor Hallucis Longus Osteomuscular Flap, Radial Forearm Flap, Rectus Abdominis Flap, Iliac Crest Free Flap, Latissimus Dorsi Myocutaneous Flap and Anterolateral Thigh Flap [6,7]. Therefore, it is recommended as the first reconstructive option for the facial región.

Maxillar tumors involve two main sites: the palate (oral cavity) and the maxillary sinus. Malignancies of the paranasal sinus account for $0.2 \%$ of all malignancies and 3\% of all malignancies of the upper digestive tract [8-10]. Palate tumors account for $8 \%$ of the tumors of the oral cavity and $5 \%$ of all malignancies of the upper digestive tract $[11,12]$.

Treatment of these tumors usually requires a combination of surgical resection followed by radiotherapy [13-15]. The resulting defects involve disruption of the soft tissue and the bones of the palate and the mid-third región. Loss of these structures may have important functional and cosmetic consequences [16-18].

${ }^{\star}$ Correspondence to: David R. De Rungs Brown, Hospital General de Mexico, Dr. C Paseo Bugambilias 1000, CP 05121. Mexico City, Mexico, Tel: +52.1.55.2499.32.15; Email: de_rungs@hotmail.com

Key words: Microvascular free flaps, maxillofacial surgery, microsurgery, head and neck surgery

Received: April 02, 2018; Accepted: April 13, 2018; Published: April 17, 2018 

review

Anterolatral Thigh Flap (ALT) and Radial Forearm Flap are the most convenient for the surgeon, since it can satisfy almost all of the important defects that can be found after ablative surgery of the maxillofacial región $[19,20]$. Therefore, a meta-analysis was carried out based on the case reports and techniques used, describing the statistical analysis of each one of the main free flaps used for immediate reconstruction of the maxillofacial region [20].

\section{Objective}

Evaluate and discuss the free flap reconstructive options, as well as the description of a case with immediate reconstruction with ALT free flap for patients with total maxillectomy defects.

\section{Methods}

A comparative analysis was carried out with eight databases in searching for articles published in the last 10 years. Nine articles were selected and tested for data homogenity using the Breslow-Day Odds Ratio statistic test. These studies were combined and the positive and negative predictive values were calculated by Cochran-MantelHaenszel. Findings were identified and compared in the results of different flaps for immediate reconstruction of the maxillary region in post-oncological patients. Subsequently, a succesful reconstruction case with ALT is described as an example. In this article we present a seires of patients with varying maxillectomy defects undergoing free flap reconstructions. We describe the succesful separation of the oral and sinonasal cavities, complications and progression of each one. We evaluated the success of these techniques with presentations of some of these specific cases, identifying factors that may help in the flap selection for specific maxillectomy defects.

\section{Clinical case}

A clinical case concerning the subject is presented.

A 56-year-old male with history of type II Diabetes Melltius who began her current condition two years ago with increase of volume in her left cheek after noticing growth in the left side of her face. She seeks evaluation from a dentist for tumoral assessment. A biopsy was performed resulting in left maxillary osteosarcoma. She later seeks reconstructive and oncological evaluation where a plan for wide tumoral resection and immediate reconstruction with ALT flap is made.

A wide tumoral resection with total maxillectomy is performed, the facial artery and vein are identified, an-ALT flap is dissected, anastomosis of the pedicles $1: 1,1: 1.5$ for the vein is done, the flap is reconstructed and modelling of the exposed area is done. A primary closure is performed.

A super slim ALT flap has been described. It has a 4-5 mm width. Some technical points in the procedure were: the thinning should be performed in the flap, except around the vascular perforator, where only about $1 \mathrm{~cm}$ of adipose tissue should remain surrounding the perforating recipient. Therefore, the vascular pedicle is separated after the thinning to an average length of $8 \mathrm{~cm}$. Finally, the thickness of the flap remains with a layer of fat lobes that must be approximately 3-4 $\mathrm{mm}$, forming an almost uniformly mattress for the bony points of the flap.

Radical left maxillectomy was performed. A great maxillary defect was left measuring around $12 \times 10 \mathrm{~cm}$ (figure 2). An ALT free flap of the perforator $(16 \times 12 \mathrm{~cm})$ was performed in the left thigh (figure $3 \mathrm{~A}$ ).

The ALT free flap was performed for the reconstruction of the external facial defect and the perforator was anastomosed under the microscope with the facial artery and vein. On the other hand, through the elliptical incisión, the surrounding pediculated flap $(10 \times 12 \mathrm{~cm})$ was designed (Figures 1-5).

\section{Results}

The four main free flaps used for the immediate reconstruction of the maxillar región $(\mathrm{n}=94.0)$ with better long-term integration response as well as functional and aesthetic compliance in the postoncological reconstructive procedure of the facial region were: Radial Forearm Falp, Anterolateral Thigh Flap, Fibula-Flexor Hallucis Longus Osteomuscular Flap, Latissimus Dorsi Myocutaneous Flap. We identified 94 patients with maxillary and palatal osteosarcoma in $60 \%$ of the diagnoses, in which the findings of adequate integrity for

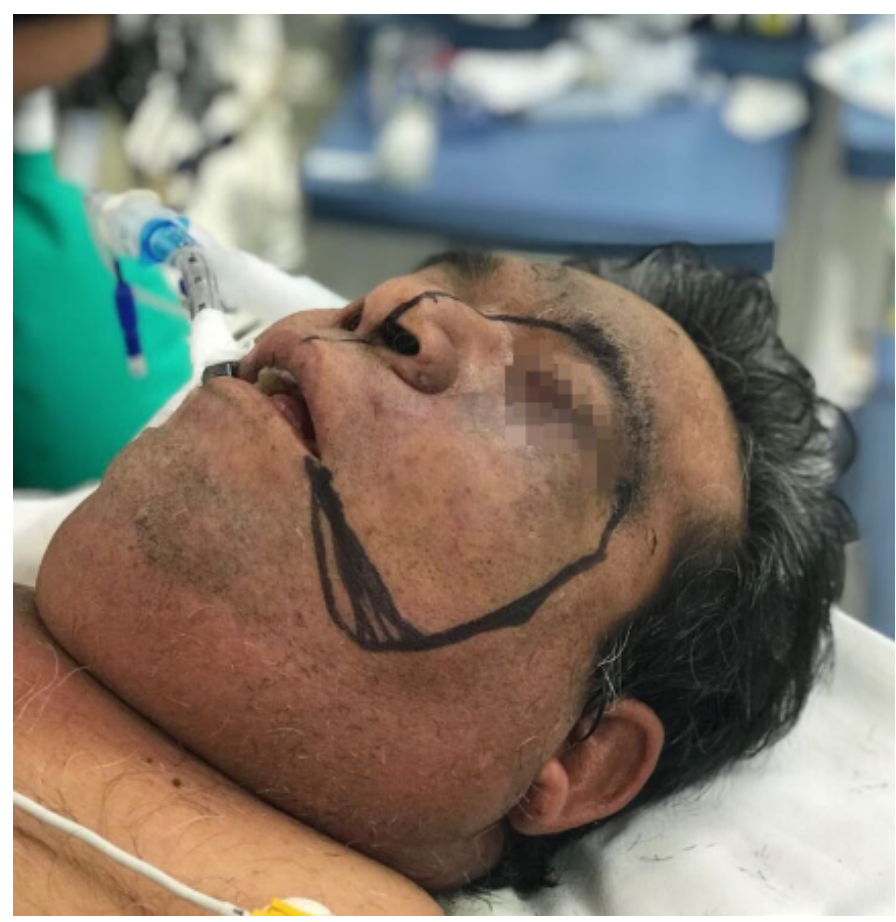

Figure 1. Tumor Markings Resection pre- operation

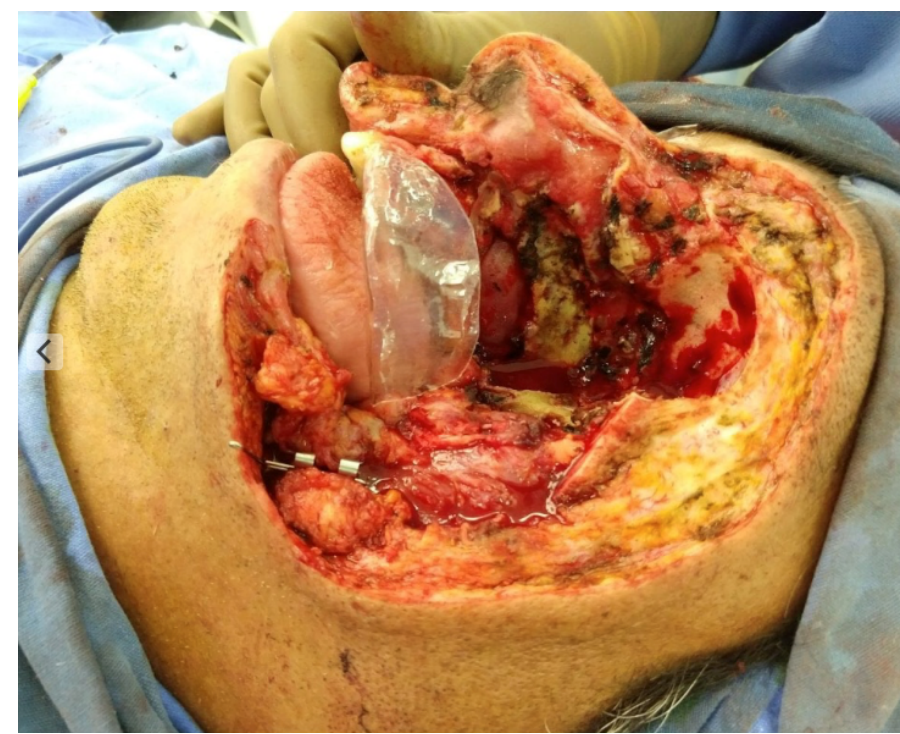

Figure 2. Oncologic Resection Area 


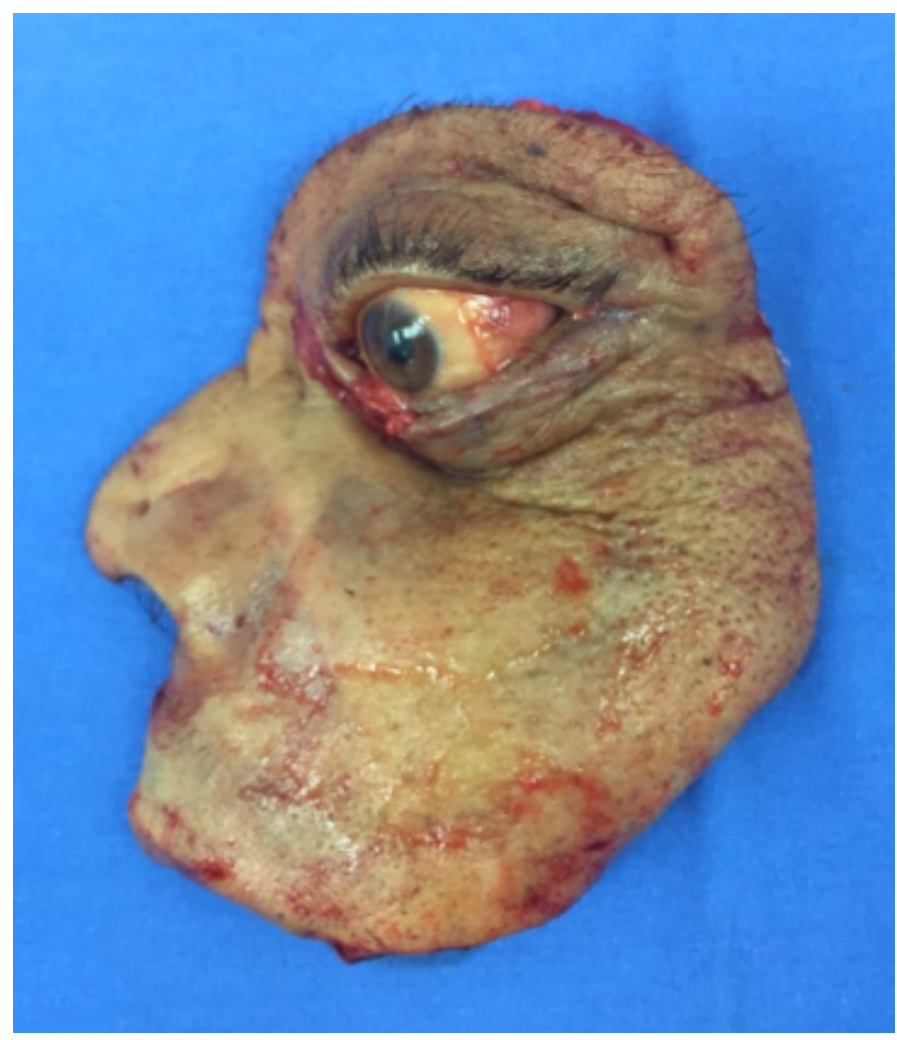

Figure 3. Oncologic Tumor Pathologic Piece.

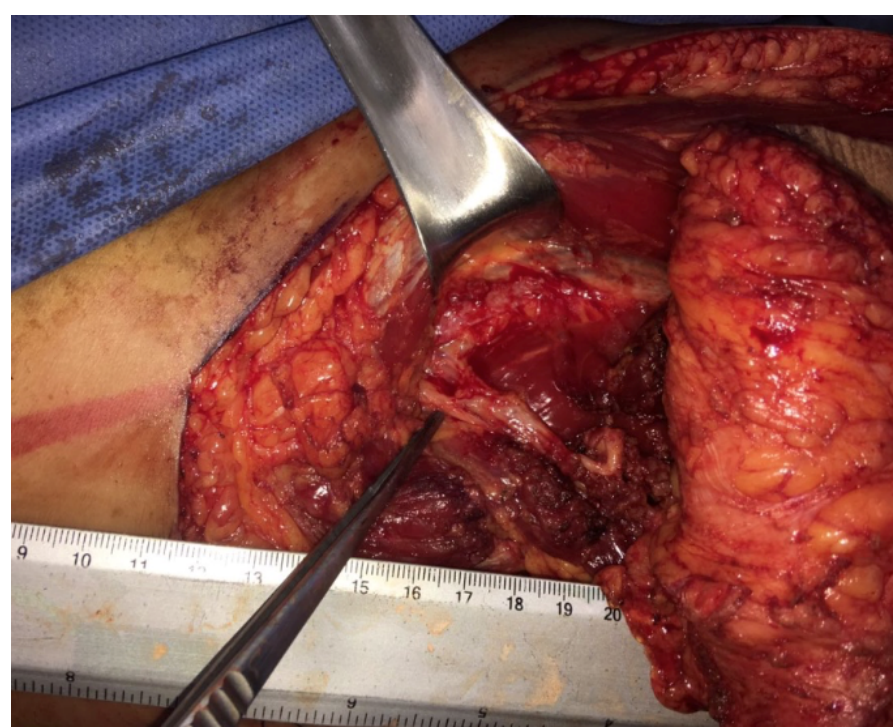

Figure 4. ALT Pedicle

each of the flaps were: Radial Forearm Flap PPV of 7.9 (7.3 to 8.5), (Chart 2) Fibula-Flexor Hallucis Longus Osteomuscular Flap with a PPV of 4.2 (1.1-6.3) (Chart 3). The $87 \%$ of the patients correlated with the initial oncological diagnosis with previous biopsy and oncological protocol for disease-free resection. Radial Forearm Flap with a PPV of $2.8(0.8-8.6)$ and Anterolateral Thigh Flap with a PPV of $1.6(1.0-2.5)$ which represented $95 \%$ of the procedures with better prognosis and correlated with the clinical findings and survival of the flap. 23 patients, who attributed to $18 \%$ of the free flaps used, presented complications, and $75 \%$ of the free flaps described did not present complications (Charts 1 and 4).

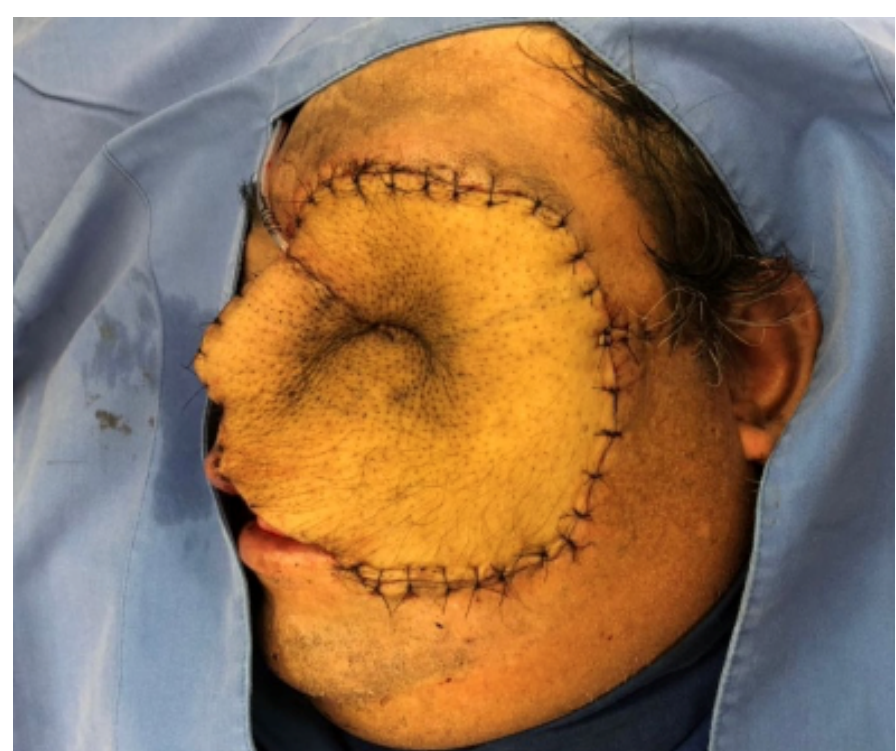

Figure 5. Free ALT Flap for Facial Reconstruction.
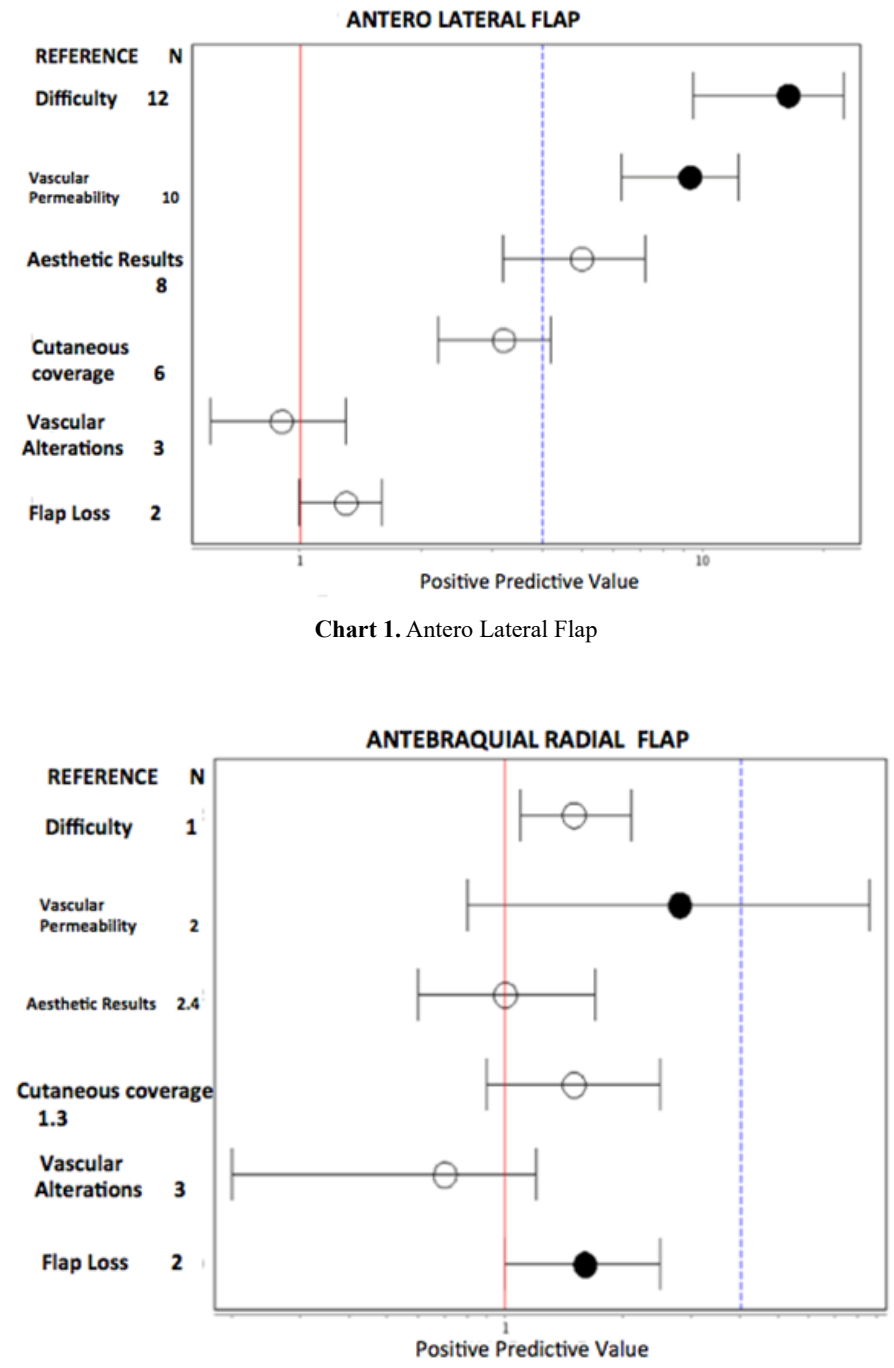

Chart 2. Antebraquial radial flap 


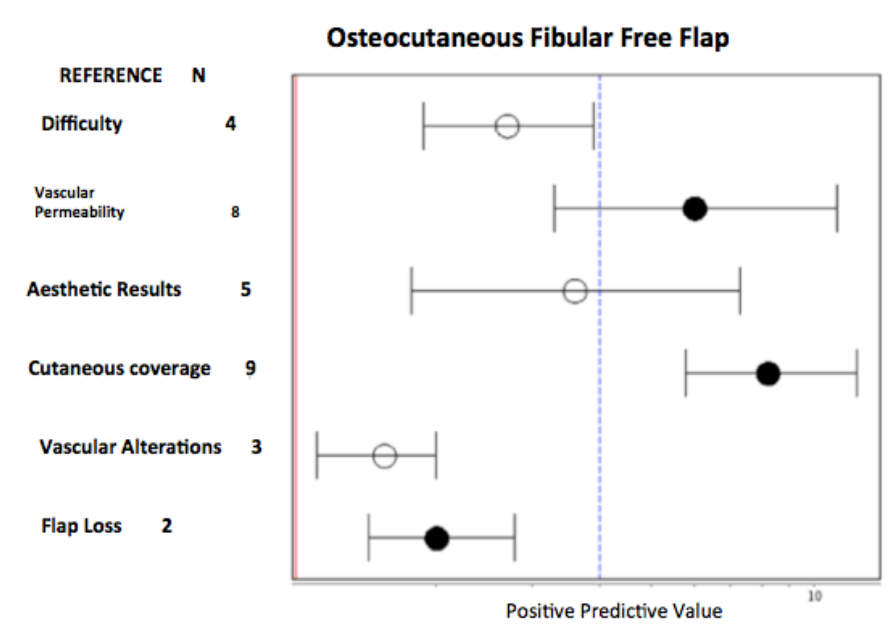

Chart 3. Osteocutaneous fibular free flap

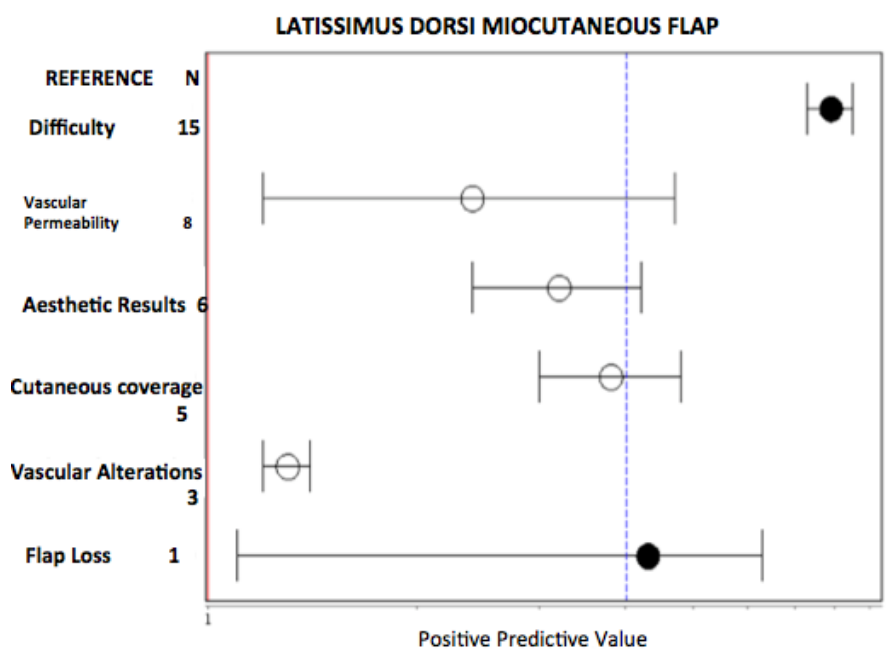

Chart 4. Lattissimus dorsi miocutaneous flap

Complications with flaps; Radial Forearm Flap with PPV of 9.5 (16.3 to 22.4) and Anterolateral Thigh Flap with a PPV of $6.3(09.03$ to 12.03 ). The remaining $10 \%$ of the flaps were 31 patients presenting comorbidities such as hypertension with a PPV of 6 (3.3 to 11.0), diabetes mellitus with a PPV of $8.2(5.8-12)$ and smoking with a positive predictive value of $2(1.5-2.8)$.

\section{Conclusion}

The reconstruction of the defects of partial and/or total maxillectomy as well as madibulectomy, may have variable requirements of soft tissue and bone, which are determined by the degree of resection [21,22]. Many of these defects result in important functional and aesthetic sequelae. These may include infraposition of the lip, the malar region as well as infraorbital soft tissues, hemilabial loss with compromise of the oral phase of swallowing, difficulty with speech articulation and mastication as well as complications of the orbital contour [23-25].

In some cases in which the eyeball is released and there is a lack of support of the orbital floor can result in ectropion, enophthalmos, vertical dystopia, diplopia and ectropión $[26,27]$. The objectives of reconstructing maxillar defects include; obtaining a consistently well-addressed wound, restoration of palatal capacity and function (separation of the oral and nasal cavities), orbital support or filling of the orbital cavity in cases of exenteration, obliteration of the maxillectomy defect and restore the damaged facial contours [28-30].

Locally advanced alignancies in the facial region are rare. However, when present, they impart a significant reconstructive challenge. These tumors have a tendency to invade peripheral tissues that cover a large area, as well as exposing deeper structures such as the skull, dura mater, orbit, and the sinus after resection $[31,32]$. The dilemma reconstructive posto-clinical patients are the high incidence of previous surgery in the region, as well as adjuvant radiotherapy, which may prevent the use of local flaps or skin grafts. The free tissue transfer allows the surgeon to provide a well-vascularized tissue with adequate volume that is not limited by the arc of rotation [33].

The most important thing, however, is that the transference of free tissue allows an oncologist the ability to remove the tumor completely without compromising the surgical margins [34].

The selection of the free flap has been determined by a variety of factors. The amount of cutaneous coverage, location and quality of the receptor tissues of the facial region, dentition and quality of the alveolar arch to determine dental prostheses. The selection of flaps with bone was determined for patients with palate and jaw defects, in which the retention was enough for dental prostheses, in such a way that the fasciocutaneous and myocutaneous free flaps could be used, the osseocutaneous free flaps were not considered adequate for the placement of osseointegrated implants. The free flaps were used for the Radial Forearm Flap to improve the contour of the anterior arch and minimal defects of the facial region $[34,35]$.

The maxillar reconstruction with free flaps creates an important and permanent seal of the oral and sinonasal cavity in a single surgical time. Like this, the postoperative results may show a better response with the possibility of dental rehabilitation by restoring the masticatory and phonatory functions [35]. The free flap reconstruction also provides a good cosmetic result, which improves the patients' perspective and contributes to their general well-being. Free flaps are designed to adapt to specific maxillary defects and the patient's needs to provide optimal functional and cosmetic results [36].

\section{References}

1. Urken ML (2003) Advances in head and neckreconstruction. Laryngoscope 113:14731476.

2. Rosenthal E, Carroll W, Dobbs M, Scott Magnuson J, Wax M, et al. (2004) Simplifying head and neck microvascular reconstruction. Head Neck 26:930-936. [Crossref]

3. Gabr EM, Kobayashi MR, Salibian AH, Armstrong WB, Sundine M, et al. (2004) Oromandibular reconstruction with vascularized free flaps: A review of 50 cases. Microsurgery 24:374-377. [Crossref]

4. Urken ML, Buchbinder D, Weinberg H, Vickery C, Sheiner A, et al. (1991) Functiona evaluation following microvascular oromandibularre construction of the oral cancerpatient: A comparativestudy of reconstructed and non reconstructed patients. Laryngoscop 101:935-950. [Crossref]

5. Wei FC, Demirkan F, Chen HC, Chen IH (1999) Double free flaps in reconstruction of extensive composite mandibular defects in head and neckcancer. Plast Reconstr Surg 103:39-47. [Crossref]

6. Bianchi B, Ferri A, Ferrari S, Copelli C, Poli T, Sesenna E (2008) Free and locoregional flap associations in the reconstruction of extensive head and neckdefects. Int J Oral Maxillofac Surg 37:723-729. [Crossref]

7. Kim EK, Evangelista M, Evans GR (2008) Use of free tissuetransfers in head and neck reconstruction. J Craniofac Surg 19:1577-1582. [Crossref]

8. Ferri J, Piot B, Ruhin B, Mercier J (1997)Advantages and limitations of the fibula free flap in mandibular reconstruction. J Oral Maxillofac Surg 55:440-448.[Crossref]

9. Schrag C, Chang YM, Tsai CY, Wei FC (2006) Complete rehabilitation of the 
De Rungs- Brown DR (2018) Free flaps in head \& neck surgery as an option for immediate facial reconstruction: Experience in a public institution and literature review

mandiblefollowingsegmentalresection. J Surg Oncol. 94:538-545. [Crossref]

10. Urken ML, Bridger AG, Zur KB, Genden EM (2001) The scapularosteofasciocutaneousflap: A 12-year experience. ArchOtolaryngol Head NeckSurg 127:862-869. [Crossref]

11. Rees TD, Ashley FL, Delgado JP (1973)Silicone fluid injectionsfor facial atrophy: A ten-yearstudy. Plast ReconstrSurg52:118-127. [Crossref]

12. Kanchwala SK, Bucky LP (2003) Facial fatgrafting: The searchforpredictableresults. Facial Plast Surg19:137-146. [Crossref]

13. MordickTG, Larossa D, Whitaker L (1992) Whitaker softtissuereconstruction of the face: A comparison of dermal fatgrafting and vascularizedtissue transfer. Ann Plast Surg29:390-396. [Crossref]

14. Schmelzeisen R, Hausamen JE, Neukam FW, Schliephake H (1994) Microsurgicalreanastomosis of scapulatransplantsformaxillofacialbonereconstruction. FortschrKieferGesichtschir39:67-70.[Crossref]

15. Smith AA, Manktelow RT (1994) The use of free tissue transfer torestore facial contour. Clin Plast Surg17:655-661.[Crossref]

16. Losken A, Carlson GW, Culbertson JH, Scott Hultman C, Kumar AV,et al. (2002) Omental free flapreconstruction in complex head and neckdeformities. Head Neck24:326-331.[Crossref]

17. Walkinshaw M, Caffee HH, Wolfe SA (1983)Vascularizedomentumfor facial contourrestoration. Ann Plast Surg 10:292-300.[Crossref]

18. Upton J, Albin RE, Mulliken JB, Murray JE (1992) The use of scapular and parascapularflapsforcheekreconstruction. Plast ReconstrSurg90:959-971.[Crossref]

19. Harashina T, Fujino T (1981)Reconstruction in Romberg'sdiseasewith free groinflap Ann Plast Surg7:289-294.[Crossref]

20. Koshima I, Inagawa K, Urushibara K, Ohtsuki M, Moriguchi T (2000) Deep inferior epigastricperforator dermal- fatoradiposalflapforcorrection of craniofacialcontourdeformities. Plast ReconstrSurg106:10-15.[Crossref]

21. dos Santos LF (1984) The vascular anatomy and dissection of the free scapularflap. Plast ReconstrSurg73:599-604.[Crossref]

22. Kim PS, Gottlieb JR, Harris GD, Nagle DJ, Lewis VL (1987) The dorsal thoracic fascia: Anatomicsignificancewithclinicalapplication in reconstructivemicrosurgery. Plast ReconstrSurg79:72-80.[Crossref]
23. Rogers BO (1963)Progressive facial hemiatrophy (Romberg'sdisease): A review of 772 cases. In Transactions of the Third International Congress of PlasticSurgery. Washington, D.C. Excerpta Medica 681-9. [Crossref]

24. Anderl H (1979) Free vascularizedgroinfatflap in hypoplasia and hemiatrophy of the face (a 3 yearsobservation). J MaxillofacSurg7:327.

25. De la Fuente A, Jimenez A (1989)Latissimusdorsi free flapforrestoration of facial contourdefects. Ann Plast Surg 22:1-8.[Crossref]

26. Angel MF, Bridges RM, Levine PA, Cantrell RW, Persing JA (1992) The serratus anterior free tissue transfer forcranio facial reconstruction. J CraniofacSurg3:207-212. [Crossref]

27. Longaker MT, Siebert JW (1995) Microvascular free flap correction of severehemi facialatrophy. Plast Reconstr Surg 96:800-809.[Crossref]

28. Siebert JW, Anson G, Longaker MT (1996) Microsurgical correction of facial asymmetry in 60 consecutive cases. Plast Reconstr Surg 97:354-363. [Crossref]

29. Dunkley MP, Stevenson JH (1990)Experiencewith the free inverted groinflap in facial softtissue contouring: A reporton 6 flaps. Br J Plast Surg 43:154-158.[Crossref]

30. Tweed AE, Manktelow RT, Zuker RM (1984) Facial contourre construction with free flap. Ann Plast Surg12:313-320.[Crossref]

31. Harashina T, Fujino T (1981) Reconstruction in Romberg's disease with free groinflap. Ann Plast Surg 7:289-294. [Crossref]

32. Shintomi Y, Ohura T, Honda K, Iida K (1981) The reconstruction of progressive facial hemi-atrophy by vascularized dermis-fatflaps. Br J Plast Surg 34:398-409.

33. Vaienti L, Soresina M, Menozzi A (2005)Parascapular free flap and fatgraft: Combined surgical methods in morphological restoration of Hemifacial Progressive Atrophy. Plast ReconstrSurg 116:699-711. [Crossref]

34. Jallali N, Ridha H, Butler PE (2005) Postoperative monitoring of free flaps in UK plastic surgery units. Microsurgery 25:469-472. [Crossref]

35. Whitaker IS, Gulati V, Ross GL, Menon A, Ong TK (2007)Variations in the postoperative management of free tissue transfers to the head and neck in the United Kingdom. Br J Oral Maxillofac Surg 45:16-18.[Crossref]

36. Whitaker IS, Oliver DW, Ganchi PA (2003)Postoperativemonitoring of microvascular tissue transfer: Currentpractice in the United Kingdom and Ireland. Plast Reconstruct Surg 111:2118-2119. [Crossref]

Copyright: (C2018 De Rungs- Brown DR. This is an open-access article distributed under the terms of the Creative Commons Attribution License, which permits unrestricted use, distribution, and reproduction in any medium, provided the original author and source are credited. 